\section{Joint destruction and chondrocalcinosis in patients with generalised osteoarthrosis}

Both generalised osteoarthrosis (GOA) and articular chondrocalcinosis (ACC) become more frequent with increasing age. Destructive changes, especially of the finger, knee, or hip joints, may be a complication of osteoarthrosis. ${ }^{12}$ Similar destructive arthropathies have recently been described in patients with ACC. ${ }^{3}{ }^{4}$ Nevertheless, the relation between GOA and ACC and between these two conditions and destructive arthropathies is still not clear. We therefore studied new patients with GOA to evaluate the incidence of ACC and destructive arthropathies among them.

\section{Patients, methods, and results}

Consecutive new patients with clinical suspicion of generalised osteoarthrosis (GOA) were investigated. $X$-ray films of the hands, knees, pelvis, and shoulders were taken. The diagnosis of GOA was based on radiological evidence of degenerative joint disease, such as asymmetrical narrowing of the joint space, sclerotic changes of adjacent bone, and presence of osteophytes, in six joints or groups of small joints (but excluding the spine, the feet and the elbows); 72 consecutive patients with the diagnosis of GOA as described above were evaluated. Articular chondrocalcinosis (ACC) was diagnosed on the radiographs, when two joints at least showed clear-cut signs of typical calcifications in cartilage. Destructive arthropathy was diagnosed when an interruption of articular surfaces with bony erosions and irregularities were seen on the radiographs. The erosive osteoarthrosis of the distal and proximal interphalangeal finger joints was classified separately from that affecting the other joints. Patients with known other causes for joint destruction such as sensory neuropathy, hyperparathyroidism, haemochromatosis, urate gout, rheumatoid arthritis, and a history of corticosteroid therapy were excluded from the study.

The results are presented in the table. ACC was found in 15 patients, an incidence of $20.8 \%$. Among these 15 patients, the sex ratio and the mean age were very similar to those of the patients with GOA only. Both groups had a similar incidence of Heberden's and Bouchard's nodes and of erosive osteoarthrosis of the finger joints. Nevertheless, destructive changes of large joints were significantly more frequent in the patients with ACC; nearly half of them had some, as opposed to only four of the remaining patients.

Composition of groups and clinicul results

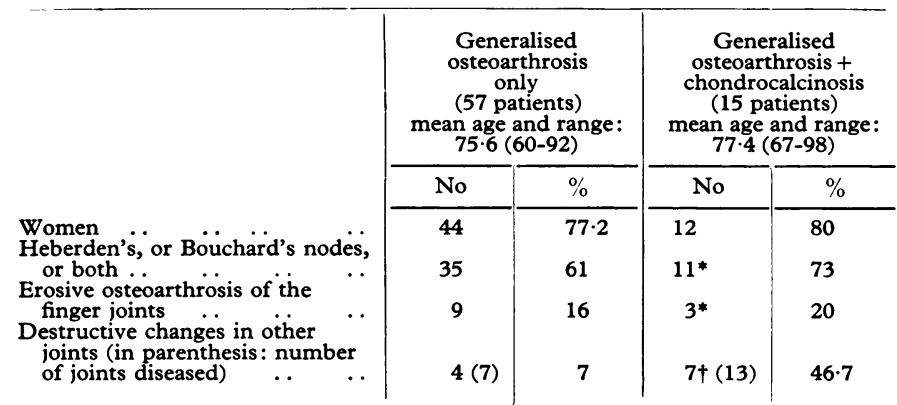

*NS (chi square with Yates's correction).

$\dagger \mathrm{P}<0.001$ compared with the group having GOA only (chi square with Yates's correction).

\section{Discussion}

The destructive arthropathy described in association with ACC might have been primarily related to osteoarthrosis, which also predisposes to joint destruction-especially in the hips and knees. Such changes could be observed more often because patients with ACC are more extensively studied with radiographs. Our prospective study clearly indicates that destructive arthropathy is associated with ACC. The results are consistent with our previous study, when a group of patients with ACC and GOA were compared with a matched group with GOA alone and a clear-cut association between ACC and destructive arthropathy was found. ${ }^{5}$ In GOA the destructive changes were in the femoral head or in the knee joints, whereas in patients with GOA and ACC other joints were frequently diseased, such as the shoulders, wrists, and elbows. Furthermore, the present study supports the view that the erosive osteoarthrosis of the fingers is not more frequent in the group with ACC than in the group with GOA alone.

1 Peter, J B, Pearson, C M, and Marmor, L, Arthritis and Rheumatism, 1966, 9, 365.

2 Harrison, M H, Schajowicz, F, and Trueta, J, fournal of Bone and foint Surgery, 1953, 35B, 598

${ }^{3}$ Menkes, C J, et al, Revue du Rhumatisme, 1973, 40, 115.

${ }^{4}$ Richards, A J, and Hamilton, E B D, Annals of the Rheumatic Diseases, 1974, 33, 196.

5 Gerster, J C, Vischer, T L, and Fallet, G H; fournal of Rheumatology, 1975 , in press.

Division of Rheumatology, University Department of Medicine, Hôpital Beau-Séjour, CH-1211 Geneva 4, Switzerland

J C GERSTER, MD, senior medical registrar

T L VISCHER, MD, consultant physician

I BOUSSINA, MD, senior medical registrar

G H FALLET, professor of rheumatology

\section{Thermographic diagnosis of deep vein thrombosis}

There is a need for a simple, non-invasive technique for diagnosing deep vein thrombosis (DVT). Thermography is both simple and noninvasive. Cooke and Pilcher ${ }^{1}$ reported a good correlation between the results of thermography and phlebography in acute DVT, while Franco et $a l^{2}$ reported a good agreement between abnormal lung perfusion scans and thermography in the investigation of a small group of patients with suspected pulmonary embolism. With an acute DVT in the leg there is a subclinical increase in skin temperature due to the inflammatory reaction round the thrombus and also to the increased blood flow in the skin. ${ }^{34} \mathrm{We}$ report here a comparative study of thermography and phlebography in the diagnosis of DVT.

\section{Patients, methods, and results}

From November 1974 to May 197551 legs in 50 patients with a mean age of 61 years (range 16-85) were examined by both thermography and ascending phlebography. In each case both examinations were done within 24 hours of each other. The AGA Medical System (AGA 680) was used for thermography and the thermographic oscilloscope pictures were taken by Kodak Tri-X film, 400 ASA. The front of the thigh and leg and the popliteal fossa and calf were studied in all cases.

The results of thermography and phlebography in 51 legs are shown in the table. They represented a diagnostic agreement of $92 \cdot 2 \%$.

\begin{tabular}{l|c|c}
\hline \multirow{2}{*}{ Phlebography } & \multicolumn{2}{|c}{ Thermography } \\
\cline { 2 - 3 } & Positive & Negative \\
\hline Positive & 27 & 2 \\
Negative & 2 & 20 \\
\hline
\end{tabular}

The temperature in affected legs was higher than in normal legs, and pretibial or prepatellar cooling, or both, were absent or diminished. In a few cases a hot streak corresponded with the position of the thrombus. In two cases the diagnosis of DVT was positive by phlebography but negative by thermography. One was a case of prostatic carcinoma with extensive DVT more than 14 days' old. The other was a case of minimal thrombosis in a 
calf vein. In two cases the thermograms were positive by our criteria but DVT was not shown on the phlebograms. In one of the cases there was extensive superficial thrombophlebitis in the thermographically positive leg. In the other case we were unable to explain the discrepancy.

\section{Comment}

These results agree with those of Cooke and Pilcher. ${ }^{1}$ We conclude that thermography is a simple, non-invasive method of investigating cases of acute DVT and that its diagnostic value is comparable to that of phlebography.

1 Cooke, E D, and Pilcher, M F, British fournal of Surgery, 1974, 61, 971.

2 Franco, J, et al, fournal of Nuclear Medicine, 1974, 16, 438.

3 Provan, J L, British Medical fournal, 1965, 2, 334.

4 Hallböök, T, and Ling, L, Acta Chirurgica Scandinavica, 1972, 138, 581. Sweden

D BERGQVIST, MD

$S$ DAHLGREN, MD

O EFSING, MD

T HALLBÖOKK, MD
Departments of Surgery and Radiology, Kärnsjukhuset, Skövde,

was measured by a Wright peak flow meter, the best of three readings taken 10 and 5 minutes before treatment and every 10 minutes during the infusion, and arterial gases (Astrup micro-method) at 0,15 , and 60 minutes. Pulse and blood pressure were recorded every 10 minutes and the electrocardiograph monitored continually. Patients given an intravenous bronchodilator within 3 hours before admission were excluded.

Results were analysed as the mean peak increase or decrease during drug administration and also as the average increase (or area under the curve), using a $t$ test for unpaired samples. Eleven patients received salbutamol and 9 aminophylline. Both drugs produced a significant increase in PFR, greater after salbutamol, though the difference between the drugs was not statistically significant (see table).

Pulse rate fell after aminophylline but not after salbutamol, the difference between the two being significant. The diastolic blood pressure fell after salbutamol but not after aminophylline. No significant changes in blood gases occurred after either drug. Side effects occurred in 7 of the 9 patients given aminophylline and in 5 of the 11 given salbutamol. Two given aminophylline and 3 given salbutamol experienced headache. Three of the aminophylline group and 2 of the salbutamol group experienced tremor. Nausea (4 patients), vomiting ( 1 patient), and ventricular extrasystoles (4 patients) occurred only in those given aminophylline. In one patient, who also had mitral valve disease, the ventricular extrasystoles became fewer during the salbutamol infusion. No significant changes occurred in the serum potassium during the infusion in either group.

\section{Discussion}

The optimum dose and mode of administration of intravenous salbutamol in acute severe asthma are yet to be decided. Fitchett $e t$ al gave it as a bolus injection over one minute and May et $a l^{4}$ as an infusion in doses of 4 to $25 \mu \mathrm{g} / \mathrm{min} .{ }^{4}$ May et al, who were investigating patients recovering from an asthmatic attack, concluded that salbutamol infused at $4 \mu \mathrm{g} / \mathrm{min}$ provides adequate bronchodilatation with no cardiovascular side effects and a considerable safety margin. Because our patients were severely ill on admission we decided to give a larger dose as a continuous infusion over one hour. The dose of aminophylline corresponds to that recommended in a recent editorial. ${ }^{2}$

Salbutamol given in this manner produced in our patients a rapid and progressive rise in peak flow rate at least as effectively as aminophylline and with fewer side effects. Probably intravenous salbutamol will assume an important place in the management of patients severely ill with acute asthma, especially in the initial period before corticosteroids have had $t$ :me to work.

We thank Mr J Davies of Allen and Hanbury for help with this study.

Bronchodilators are essential in the treatment of severe asthma because produces a number of undesirable side affects ${ }^{2}$ Intravenous salbutamol is an effective bronchodilator. ${ }^{3}$ We report a double blind trial of intravenous aminophylline and salbutamol in the initial treatment of patients with life-threatening asthma.

\section{Patients, methods, and results}

Twenty hospital patients with severe asthma, with a pulse rate of $>120 /$ min, peak flow rate (PFR) $<25 \%$ predicted, and $\mathrm{PaO}_{2}<9.3 \mathrm{kPa}(69.8 \mathrm{~mm}$ $\mathrm{Hg}$ ) gave informed consent. All were given $1 \mathrm{~g}$ of hydrocortisone intravenously initially and oxygen by $28 \%$ Ventimask (except during the five minutes before each arterial puncture). Either aminophylline $0.5 \mathrm{~g}$ or salbutamol $500 \mu \mathrm{g}$ was given intravenously over one hour by constant rate infusion pump. They were dispensed in identical ampoules, labelled by number, and allocated randomly and double blind. Response to treatment

Collins, J V et al, Quarterly fournal of Medicine, 1975, 44, 259.

Lancet, 1973, 2, 950.

Fitchett, D H, McNicol, M W, and Riordan, J F, British Medical fournal, $1975,1,53$.

${ }^{4}$ May, C S, et al, Thorax, 1975, 30, 236.

Llandough Hospital, Penarth, and Asthma Research Unit, Sully

Hospital, Penarth, Glamorgan

S J WILLIAMS, MB, MRCP, medical registrar

R W PARRISH, MB, house physician

A SEATON, MD, MRCP, consultant physician

Comparative effects of aminophylline and salbutamol. Means $( \pm S D)$ of firdings in 20 patients with acute asthma

\begin{tabular}{|c|c|c|c|c|c|c|c|c|c|}
\hline & & \multirow{2}{*}{$\begin{array}{c}\text { Before } \\
\text { treatment }\end{array}$} & \multicolumn{7}{|c|}{ Minutes after start of infusion } \\
\hline & & & 10 & 15 & 20 & 30 & 40 & 50 & 60 \\
\hline Peak flow rate $(1 / \mathrm{min})$ & $\stackrel{\mathrm{A}}{\mathrm{S}}$ & 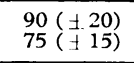 & $\begin{array}{r}104( \pm 27) \\
90( \pm 25)\end{array}$ & $=$ & $\begin{array}{l}109( \pm 34) \\
114( \pm 27)\end{array}$ & $\begin{array}{l}118( \pm 43) \\
128( \pm 53)\end{array}$ & $\begin{array}{l}122( \pm 50) \\
140( \pm 55)\end{array}$ & $\begin{array}{l}131( \pm 65) \\
151( \pm 72)\end{array}$ & $\begin{array}{l}134( \pm 64) \\
161( \pm 85)\end{array}$ \\
\hline Pulse rate (min) & $\begin{array}{l}A \\
\text { S }\end{array}$ & $\begin{array}{l}125( \pm 7) \\
128( \pm 11)\end{array}$ & $\begin{array}{l}116( \pm 14) \\
128( \pm 14)\end{array}$ & 二 & $\begin{array}{l}117( \pm 11) \\
127( \pm 15)\end{array}$ & $\begin{array}{l}115( \pm 15) \\
126( \pm 14)\end{array}$ & $\begin{array}{l}117( \pm 17) \\
127( \pm 13)\end{array}$ & $\begin{array}{l}118( \pm 11) \\
126( \pm 13)\end{array}$ & $\begin{array}{l}119( \pm 11) \\
126( \pm 14)\end{array}$ \\
\hline Systolic BP (mm Hg) & $\stackrel{\mathrm{A}}{\mathrm{S}}$ & $\begin{array}{l}157( \pm 20) \\
139( \pm 17)\end{array}$ & $\begin{array}{l}153( \pm 21) \\
131( \pm 30)\end{array}$ & 二 & $\begin{array}{l}152( \pm 21) \\
130( \pm 18)\end{array}$ & $\begin{array}{l}148( \pm 17) \\
128( \pm 13)\end{array}$ & $\begin{array}{l}149( \pm 23) \\
128( \pm 11)\end{array}$ & $\begin{array}{l}149( \pm 20) \\
124( \pm 13)\end{array}$ & $\begin{array}{l}142( \pm 15) \\
126( \pm 12)\end{array}$ \\
\hline Diastolic BP (mm Hg) & $\stackrel{A}{S}$ & $\begin{array}{l}91( \pm 9) \\
87( \pm 9)\end{array}$ & $\begin{array}{l}87( \pm 11) \\
78( \pm 16)\end{array}$ & 二 & $\begin{array}{l}90( \pm 13) \\
76( \pm 12)\end{array}$ & $\begin{array}{l}87( \pm 10) \\
74( \pm 12)\end{array}$ & $\begin{array}{l}87( \pm 13) \\
70( \pm 11)\end{array}$ & $\begin{array}{l}86( \pm 11) \\
71( \pm 9)\end{array}$ & $\begin{array}{l}84( \pm 10) \\
73( \pm 7)\end{array}$ \\
\hline $\mathrm{PaO}_{2}(\mathrm{kPa})$ & $\stackrel{\mathrm{A}}{\mathrm{S}}$ & $\begin{array}{l}7 \cdot 7( \pm 1 \cdot 6) \\
7 \cdot 5( \pm 1 \cdot 1)\end{array}$ & 二 & $\begin{array}{l}7 \cdot 5( \pm 1 \cdot 3) \\
8 \cdot 4( \pm 2 \cdot 0)\end{array}$ & $=$ & 二 & 二 & 二 & $\begin{array}{l}8 \cdot 1( \pm 1 \cdot 7) \\
8 \cdot 9( \pm 1 \cdot 9)\end{array}$ \\
\hline $\mathrm{PaCO}_{2}(\mathrm{kPa})$ & $\stackrel{\mathrm{A}}{\mathrm{S}}$ & $\begin{array}{l}5 \cdot 3( \pm 1 \cdot 6) \\
5 \cdot 6( \pm 1 \cdot 2)\end{array}$ & $=$ & $\begin{array}{l}5 \cdot 6( \pm 2 \cdot 1) \\
5 \cdot 1( \pm 0 \cdot 9)\end{array}$ & 二 & 二 & 二 & 二 & $\begin{array}{l}5 \cdot 1( \pm 2 \cdot 0) \\
5 \cdot 2( \pm 0.9)\end{array}$ \\
\hline
\end{tabular}

